\title{
Effect of conventional and complete feed (mesh) feeding systems on physical conformation install fed
} goats

\begin{abstract}
To study the comparative evaluation of conventional and complete feed feeding system an experiment was conducted by taking 16 Marwari goats of same age ( 8 -10months) and uniform conformation in a randomized block design. The concentrate mixture of 20.90percent CP was formulated on dry matter basis using ingredients i.e. barley 35 parts, wheat bran 20parts, cotton seed cake 30parts, guar churi 13 parts, mineral mixture 1 part and salt 1 part. In $\mathrm{T}_{1}$ group chopped groundnut straw (Arachis hypogia) and concentrate mixture were offered separately, whereas in $\mathrm{T}_{2}$ group, groundnut straw and concentrate mixture were mixed in 60:40 ratio and were given in mixed form. The body measurements viz. live weight, length, height and girth were recorded at weekly intervals before feeding and watering of the two feeding systems were worked out. The results obtained from the comparative study of two feeding system suggest that blending of concentrate and roughage was beneficial rather than feeding them separately and that complete feeds provide uniform supply of nutrients at regular intervals which helps to improve physical conformation and maintain better digestibility of nutrients.
\end{abstract}

Volume 2 Issue I - 2015

\section{Padma Meel, Basant Bais}

Department of livestock Production and Management, Rajasthan University of Veterinary and Animal Sciences, India

Correspondence: Basant Bais, Professor and Head, Department of Livestock Products Technology, College of Veterinary and Animal Science, Rajasthan University of Veterinary and Animal science, Bikaner, India, Tel 94I 331 1741, Email basantbais@gmail.com

Received: December 18, 2014 | Published: January 05, 2015

\section{Background}

Livestock resources in India especially small ruminants like sheep and goat play an important role in economy of our country. Sheep and goat are most important ruminant species of economic value to the small and marginal farmers and landless labourers in this country. In India they constitute very valuable and renewable resources across all ecological zones and fulfill an important socio-economic role in traditional farming system. In spite of $2 \%$ of geographical area India has the pride place for livestock due to enormity of livestock wealth well amazing genetic diversity. The vast biodiversity in sheep and goat in India is represented by 42 breeds of sheep and 20 recognized breeds of goat. It has about 71.6 million sheep and 140.5 million goats accounting for $0.6 \%$ and $15.35 \%$ of respective total world population. ${ }^{1}$ Goat is an animal of great importance to the livestock industry in India and goat farming in India is the backbone of economy of small and landless farmers. Most of the researchers worked on nutritional aspect

Table I Experimental design of animals of livestock and putting joint efforts to generate data on the beneficial effects of complete feed. ${ }^{2-6}$ There is a dire need to change conventional system of feeding so as to meet the current challenge of high yielding crossbred cows and buffaloes and also improved goat for production.

\section{Material and methods}

Two groups $\left(T_{1}\right.$ and $\left.T_{2}\right)$ of eight animals each, were made for experiment. In $\mathrm{T}_{1}$ group the chopped groundnut straw (Arachis hypogia) procured locally was offered ad lib. as basal roughage and the concentrate mixture were given separately (Plate 3) in quantity sufficient to meet the nutritional requirement of goat according to Indian feeding standards (ICAR, 1985) whereas in $\mathrm{T}_{2}$ the groundnut straw and formulated concentrate mixture mixed together in form of complete ration (60:40) was offered to animals in mesh form and has been presented in Table 1 .

\begin{tabular}{|c|c|c|c|c|c|}
\hline S.no. & $\begin{array}{l}\text { Experimental } \\
\text { group }\end{array}$ & Type of ration & No. of animal & $\begin{array}{l}\text { Experimental } \\
\text { period }\end{array}$ & Digestion trial \\
\hline \multirow{3}{*}{ I } & & & & $22-12-2009$ & $14-02-2010$ \\
\hline & TI & Roughage and concentrate separately & 8-Jan & to & to \\
\hline & & & & $13-02-2010$ & $20-02-2010$ \\
\hline \multirow{3}{*}{2} & & & & $22-12-2009$ & $14-02-20 \mid 0$ \\
\hline & $\mathrm{T} 2$ & Complete feed in mesh form & 16-Sep & to & to \\
\hline & & & & $13-02-2010$ & $20-02-2010$ \\
\hline
\end{tabular}




\section{Results and discussion}

In order to study the comparative evaluation of two different feeding systems i.e. conventional and complete feed feeding system on physical conformation in Stall fed goats the observations viz. periodical body weight, length, height and chest girth were recorded to assess the effect of feeding of conventional and complete feeds in goat. The results of the experiment have been presented and discussed under the following headings.

\section{Physical conformation}

The attainment of physical biometrics parameters could be an indicator of the nutritional status of the animal. Therefore, live body weight and external body measurements viz. length, height and girth were recorded at weakly intervals before feeding and watering.

Live Weight: The live weight $(\mathrm{kg})$ of all the experimental animals were recorded for two consecutive days in each week using an Avery Plateform dial scale balance and have been presented in Table $2 \&$ Figure 4 . The body measurements were taken with the help of measuring tape, while the animals were made to stand on a leveled floor with the head held up.

Body measurements: The length, height and girth, which are usually considered as an important parameter for assessment of growth pattern were recorded at weekly intervals to compare the performance of goats in $\mathrm{T}_{1}$ (conventional feed group) and $\mathrm{T}_{2}$ (complete feed group) and have been presented in Table $3-5$.

Body length: The body lengths of goats were found to increase in almost uniform pattern with the advancement of age. The average body length in animals fed conventional and complete feed were found to be $19.04 \pm 0.63$ and $19.97 \pm 0.54$ inches, respectively, suggested significant difference due to blending of all feed stuffs in complete feed as compared to conventional feed system as shown in Table $3 \&$ Figure 1 . The analysis of variance (Table 3.1) revealed highly significant $(\mathrm{P}<0.01)$ effect of treatment and period as far as length in both the treatment groups was concerned. The period of periodical length depicted in Figure 1 suggested a uniform rising trend from 0 to 63days. These findings were in agreement with Bohrey and Jain ${ }^{7}$ and Solanki et al. ${ }^{8}$

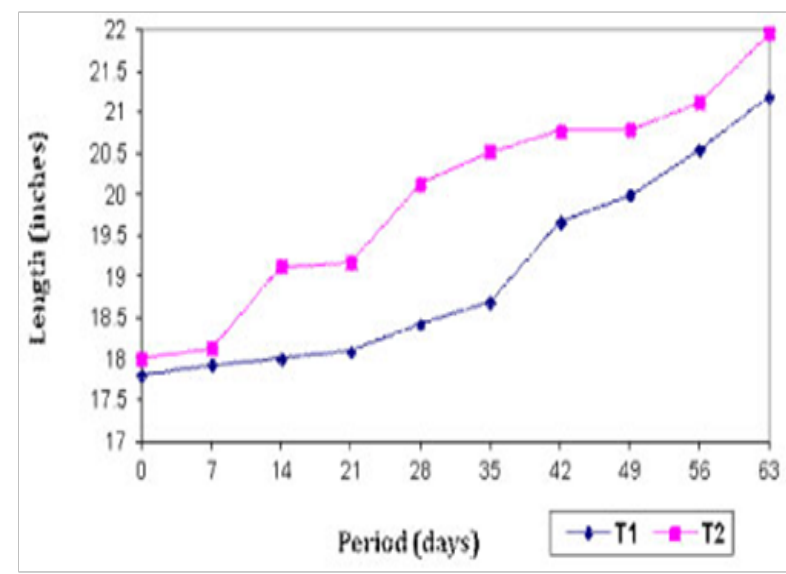

Figure I Periodical body length (inches).

Body height: The body height of goat which could be a feature of consideration for judging the influence of dietary status have been presented in Table 4 and depicted in Figure 2. The overall mean values for $\mathrm{T}_{1}$ group was $23.21 \pm 0.78$ inches, whereas for $\mathrm{T}_{2}$ value was $23.41 \pm 0.64$ inches. The statistical analysis of data (Table 4.1 ) revealed highly significant $(\mathrm{P}<0.01)$ effect of treatment and period. Similar results were recorded by Paramasivam et al. ${ }^{8}$ in Barbari goats.

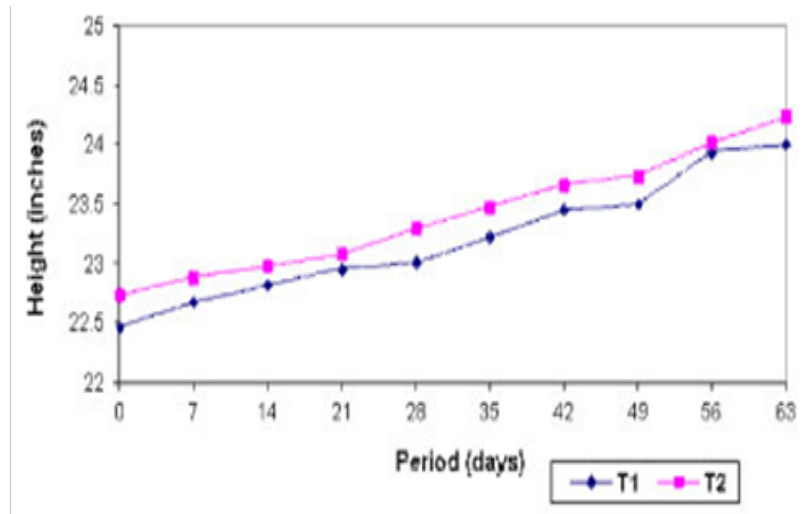

Figure 2 Periodical body height (inches).

Body girth: The girth measurement which could be referred as more reliable means for assessing the body size and the general build up of animals, reflected by different feeds i.e. conventional and complete feed have been presented in Table 5 and depicted in Figure 3. The overall mean values for conventional feed group $\left(\mathrm{T}_{1}\right)$ was $26.03 \pm 0.34$ inches, whereas for complete feed group $\left(T_{2}\right)$ value was $26.10 \pm 0.4$ inches. Results of the current experiment were in concordance with Arumugam and Thiagarajan, ${ }^{9}$ Bohrey and Jain, ${ }^{7}$ Solanki et al. ${ }^{6}$ (Table 5.1).

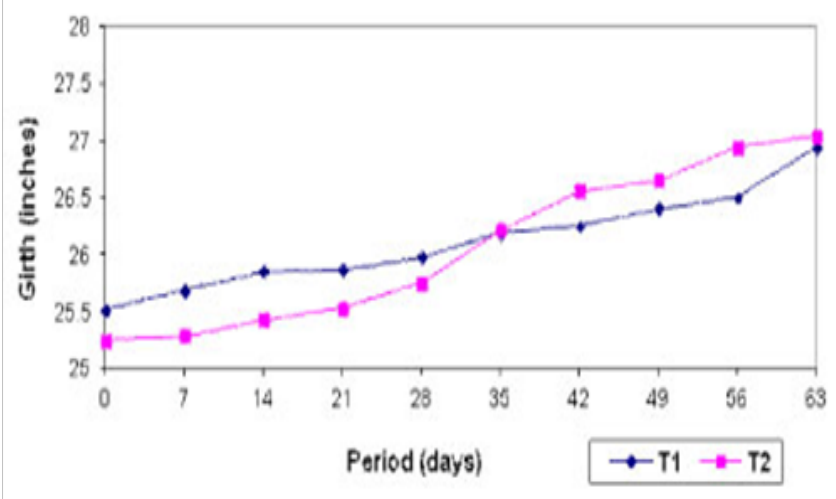

Figure 3 Periodical body girth (inches).

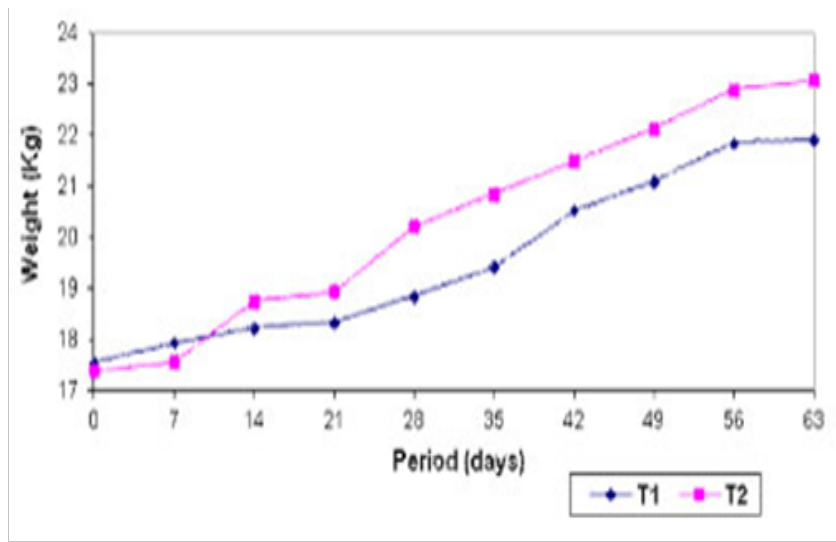

Figure 4 Periodical body weight(kg). 
Table 2 Mean value of periodical body weight (in $\mathrm{kg}$ ) of experimental goats

\begin{tabular}{llll}
\hline S.no. & $\begin{array}{l}\text { Period } \\
\text { (days) }\end{array}$ & $\begin{array}{l}\text { TI(Conventional } \\
\text { feed group) }\end{array}$ & $\begin{array}{l}\text { T2(Complete feed } \\
\text { group) }\end{array}$ \\
\hline 1 & 0 & 17.55 & 17.39 \\
2 & 7 & 17.94 & 17.57 \\
3 & 14 & 18.24 & 18.75 \\
4 & 21 & 18.35 & 18.94 \\
5 & 28 & 18.86 & 20.23 \\
6 & 35 & 19.43 & 20.86 \\
7 & 42 & 20.54 & 21.5 \\
8 & 49 & 21.11 & 22.13 \\
9 & 56 & 21.87 & 22.9 \\
10 & 63 & 21.91 & 23.09 \\
\hline Overall mean \pm SE & $19.58^{\mathrm{a}} \pm 0.46$ & $20.34^{\mathrm{b}} \pm 0.72$ \\
\hline
\end{tabular}

Table 2.I Analysis of variance of body weight (in $\mathrm{kg}$ ) in conventional and complete feed system

\begin{tabular}{lllll}
\hline Source of variance & DF & SS & MSS & F-value \\
\hline Treatment & I & 10.69 & 10.69 & $5.57^{*}$ \\
Period & 8 & 266.32 & 33.29 & 0.16 \\
Error & 126 & 752.65 & 5.97 &
\end{tabular}

*Significant at $(\mathrm{P}<0.05) 5$ percent level of probability

Table 3 Mean value of periodical body length (in inches) of experimental goats

\begin{tabular}{llll}
\hline S.No. & $\begin{array}{l}\text { Period } \\
\text { (days) }\end{array}$ & $\begin{array}{l}\text { TI(Conventional } \\
\text { feed group) }\end{array}$ & $\begin{array}{l}\text { T2(Complete feed } \\
\text { group) }\end{array}$ \\
\hline I & 0 & 17.8 & 18.01 \\
2 & 7 & 17.93 & 18.13 \\
3 & 14 & 18.01 & 19.13 \\
4 & 21 & 18.09 & 19.17 \\
5 & 28 & 18.43 & 20.13 \\
6 & 35 & 18.69 & 20.52 \\
7 & 42 & 19.67 & 20.78 \\
8 & 49 & 19.99 & 20.79 \\
9 & 56 & 20.55 & 21.12 \\
10 & 63 & 21.2 & 21.96 \\
\hline Overall mean \pm SE & $19.04^{\mathrm{a}} \pm 0.63$ & $19.97^{\mathrm{b}} \pm 0.54$ \\
\hline
\end{tabular}

Table 3.I Analysis of variance of body length (in inches) in conventional and complete feed system

\begin{tabular}{lllll}
\hline $\begin{array}{l}\text { Source of } \\
\text { variance }\end{array}$ & DF & SS & MSS & F-value \\
\hline Treatment & I & 33.1 & 33.1 & $137946.54^{* *}$ \\
Period & 8 & 144.29 & 18.03 & $10259.93^{* *}$ \\
Error & 126 & 0.01 & 0.000131 & \\
\hline
\end{tabular}

**Significant at $(\mathrm{P}<0.0 \mathrm{I})$ I per cent level of probability

Table 4 Mean value of periodical body height (in inches) of experimental goats

\begin{tabular}{|c|c|c|c|}
\hline S.no. & Period(days) & $\begin{array}{l}\text { TI(Conventional } \\
\text { feed group) }\end{array}$ & $\begin{array}{l}\text { T2(Complete } \\
\text { feed group) }\end{array}$ \\
\hline I & 0 & 22.47 & 22.74 \\
\hline 2 & 7 & 22.68 & 22.89 \\
\hline 3 & 14 & 22.82 & 22.98 \\
\hline 4 & 21 & 22.96 & 23.08 \\
\hline 5 & 28 & 23.01 & 23.3 \\
\hline 6 & 35 & 23.23 & 23.48 \\
\hline 7 & 42 & 23.46 & 23.67 \\
\hline 8 & 49 & 23.5 & 23.74 \\
\hline 9 & 56 & 23.94 & 24.02 \\
\hline 10 & 63 & 24.01 & 24.24 \\
\hline \multicolumn{2}{|c|}{ Overall mean $\pm S E$} & $23.21^{a} \pm 0.78$ & $23.4 I^{b} \pm 0.64$ \\
\hline
\end{tabular}

Table 4.I Analysis of variance of body height (in inches) in conventional and complete feed system

\begin{tabular}{lllll}
\hline Source of variance & DF & SS & MSS & F-value \\
\hline Treatment & 1 & 1.5 & 1.5 & $20419.35^{* *}$ \\
Period & 8 & 25.49 & 3.18 & $125.65^{* *}$ \\
Error & 126 & 0.01 & 0.000156 & \\
\hline
\end{tabular}

** Significant at $(\mathrm{P}<0.0 \mathrm{I})$ I percent level of probability 
Table 5 Mean value of periodical body girth (in inches) of experimental goats

\begin{tabular}{llll}
\hline S.No. & Period (days) & $\begin{array}{l}\text { TI (Conventional } \\
\text { feed group) }\end{array}$ & $\begin{array}{l}\text { T2 (Complete } \\
\text { feed group) }\end{array}$ \\
\hline 1 & 0 & 25.42 & 25.25 \\
2 & 7 & 25.61 & 25.29 \\
3 & 14 & 25.76 & 25.43 \\
4 & 21 & 25.87 & 25.63 \\
5 & 28 & 25.98 & 25.75 \\
6 & 35 & 26.09 & 26.21 \\
7 & 42 & 26.18 & 26.56 \\
8 & 49 & 26.29 & 26.65 \\
9 & 56 & 26.43 & 26.94 \\
10 & 63 & 26.72 & 27.24 \\
\multicolumn{2}{l}{ Overall mean \pm SE } & $26.03^{\mathrm{a}} \pm 0.34$ & $26.10^{\mathrm{b}} \pm 0.41$ \\
\hline
\end{tabular}

Table 5.I Analysis of variance of body girth (in inches) in conventional and complete feed system

\begin{tabular}{lllll}
\hline Source of variance & DF & SS & MSS & F-value \\
\hline Treatment & $\mathrm{I}$ & 0.19 & 0.19 & $10191.01^{* *}$ \\
Period & 8 & 29.98 & 3.74 & $1199.58^{* *}$ \\
Error & 126 & 0.04 & 0.000368 & \\
\hline
\end{tabular}

**Significant at $(\mathrm{P}<0.0 \mathrm{I})$ I percent level of probability

\section{Conclusion}

From the results of experiment under taken regarding the comparative study of two different feeding systems viz. conventional and complete feed feeding system in goat, it could be inferred that Biometric parameters viz. periodical body weight, length, height and girth in $T_{1}$ and $T_{2}$ treatment groups had highly significant effect due to treatment and period and processing of complete ration by blending roughages and concentrate will be beneficial rather than feeding them separately in a conventional form, as the complete feeds provide uniform supply of nutrients at regular intervals which helps to improve physical conformation and maintain better digestibility of nutrients. ${ }^{10}$

\section{Acknowledgements \\ None.}

\section{Conflict of interest}

Author declares that there is no conflict of interest.

\section{References}

1. Livestock Census. Annual report 2011-12. Department of Animal Husbandry, Dairying \& Fisheries, Ministry of Agriculture, Government of India. New Delhi; 2007.

2. Bais B. Nutritive evaluation of complete ration based on various levels of top feeds in Magra sheep. Bikaner: Ph. D Thesis submitted to RAU. 1995.

3. Bhatia T. Comparative evaluation of conventional and complete feed (mesh) feeding system in sheep. M.V. Sc Thesis Submitted to RAU, Bikaner; 2004

4. Reddy GVN, Reddy JL. Effect of cotton stalks based complete diet on growth and carcass characteristics in sheep and goats in field condition. Indian J Anim Nutr. 2003;20(1):97-100.

5. Singh I. Nutritional evaluation of groundnut (Arachis hypogea) straw based complete feed in loose and compressed vorm in Marwari sheep. M.V. Sc. Thesis submitted to RAU, Bikaner, Rajasthan; 2006.

6. Solanki CPS, Nanavati S, Nayak NK, et al. Growth characteristics of local goats under different managemental systems. Indian J Anim Sci. 2009;79(7):737-739

7. Bohrey AK, Jain PK. Management system effect on growth of goat kids. Indian J Anim Sci. 2004;74(8):893-895.

8. Paramasivam A, Arunachalam S, Sivakumar T, et al. Economics of body growth in barbari goats under intensive, semi-intensive and extensive systems of management. Indian Vet J. 2002;79(12):40-44

9. Arumugam R, Thiagarajan M. Performance of Tellicherry kids under range vs confined rearing systems. Cheiron. 2002;31(1,2):6-9.

10. Saini RK. Studies on nutritional evaluation and optimum utilization of methi (Trigonellafoenumgraecum) straw in complete feed of sheep. M.V. Sc. Thesis submitted to RAU, Bikaner, Rajasthan; 2008. 